\title{
Damage caused by fungi and insects to stored peanut seeds before processing
}

\author{
Franciele dos Santos ${ }^{1 \star}$, Priscila Fratin Medina ${ }^{1}$, André Luiz Lourenção², João José Dias Parisi², \\ Ignácio José de Godoy ${ }^{1}$ \\ 1. Instituto Agronômico - Centro de Grãos e Fibras - Campinas (SP), Brazil. \\ 2. Instituto Agronômico - Centro de Fitossanidade - Campinas (SP), Brazil.
}

\begin{abstract}
The aim of this study was to gather data on the incidence of fungi associated with peanut seeds stored in their pods, before being processed by the State of São Paulo seed-producing companies, and the relation of the fungi to the seed damage caused by insects and to the quality of the stored seeds. Samples were taken from seed lots of cultivars IAC 886 and IAC 503 stored by these companies at the beginning and end of a six-month storage period. The peanut seeds were shelled and half of each sample was treated with fludioxonil + metalaxyl. Untreated and treated seeds were analyzed for moisture content, germination, vigor and health. The following insects were found
\end{abstract}

to damage the peanut seeds: Cyrtomenus mirabilis (Perty) (Hemiptera: Cydnidae) and Corcyra cephalonica (Stainton) (Lepidoptera: Pyralidae). Both species reduced seed quality. When present, fungi of the genera Aspergillus, Fusarium, Penicillium and Rhizopus infected seeds and seedlings during the germination process and were considered the main limiting factor for obtaining normal seedlings. Nevertheless, despite their presence, peanut seeds maintained their germination capacity and vigor after six months of storage in their pods.

Key words: Arachis hypogaea L., germination, vigor, Cyrtomenus mirabilis.

\section{INTRODUCTION}

The State of São Paulo accounts for $89 \%$ of the Brazilian peanut crop production (CONAB 2014). The São Paulo companies that produce the grain of this oilseed crop also produce the seeds. During the postharvest management process developed by these companies, the seeds are stored in their pods in "big bags" or in bulk for at least six months without receiving any fungicidal or insecticidal treatment between harvesting and processing.

Because of their thin, fragile seed coat; large, brittle cotyledons; and the placement of the tip of the radicle near the basal surface of the cotyledons, these seeds are very susceptible to mechanical damage and insect infestations, which, in turn, promotes the entry of fungi into the seeds. Thus, due to their chemical characteristics, namely, their oil and protein richness, as well as the cultivation conditions, the seeds may have low physiological quality.
During storage, high temperatures and relative humidity can also contribute to the deterioration of these seeds because of lipid peroxidation (Nakagawa and Rosolem 2011). High relative humidity promotes the reinitiation of metabolic activity in the embryo, whereas high temperatures increase respiratory activity, which depletes reserves. In addition, these conditions may favor fungal and insect activity, thus reducing seed quality (Christensen and Kaufmann 1965). Thus, in São Paulo, the occurrence of peanut seed lots with germination percentage is often lower than the standard established for marketing (60\%), due to high rates of infection caused by fungi and insects (Santos et al. 2013).

Fungi from the field can contaminate the seeds before harvest and grow under conditions of high air relative humidity (90 to 95\%), which maintains the moisture content of the seeds between 20 and $25 \%$. At lower relative humidity, the growth of these fungi is arrested. Among these fungi, those belonging to the genus Fusarium (Thiessen and 
Woodward 2012; Santos et al. 2013) have been reported to cause rot and reduced physiological potential in peanut seeds.

The fungi that occur in storage include members of the genera Aspergillus and Penicillium, which are adapted to environments with high relative humidity (65 to $90 \%$ ) and can colonize the embryo. These fungi cause discoloration and rotting, affecting viability as well as commercial and nutritional value because of increased fatty acid content, oil rancidity and heating of the seed mass, which increases the respiratory rate and accelerates deterioration (Machado 1988; Nóbrega and Suassuna 2004; Bellettini et al. 2005; Borém et al. 2006; Santos et al. 2013). Aspergillus flavus is generally the most destructive species in peanuts (Hocking and Banks 1991). In addition, the genus Rhizopus (Ito et al. 1992; Santos et al. 2013) has been reported to cause rot and reduce seed quality in peanuts.

Insects generally attack stored seeds when the seed moisture content exceeds $13 \%$ and the temperature is between 23 and $35^{\circ} \mathrm{C}$ (Marcos Filho 2005). The rice moth, Corcyra cephalonica (Stainton) (Lepidoptera: Pyralidae), is the most important pest of stored peanuts. The larvae of this moth attack all areas of the seed and often penetrate into its interior, potentially reducing or destroying its viability (Nakagawa and Rosolem 2011). The peanut-growing area in the State of São Paulo has experienced a significant increase in soil pests, especially the burrower bug, Cyrtomenus mirabilis (Perty) (Hemiptera: Cydnidae). This insect is not a storage pest, but the damage caused by its burrowing may reduce seed physiological quality and health in the storage environment (COPLANA 2010; Santos et al. 2013).

Considering the seeds characteristics and the long storage period before peanuts are processed and treated with fungicides and/or insecticides, information about possible changes in seed quality, despite of the pod protection, due to fungal and insect activity, is required, in order to improve pest management, regarding the preservation of these seeds in the warehouses of São Paulo seed-producing companies.

Thus, the aim of this study was to ascertain the incidence of fungi in peanut seeds stored in their pods and the relation of these fungi to the damage caused by insects during storage and to peanut seed quality.

\section{METHODS}

Thirteen lots of peanuts seeds grown during the 2010/2011 growing season, including 10 from cultivar IAC 886 (lots $\mathrm{A}_{1}$,
$\mathrm{B}_{1}, \mathrm{~B}_{2}, \mathrm{~B}_{3}, \mathrm{~B}_{4}, \mathrm{~B}_{5}, \mathrm{~B}_{6}, \mathrm{C}_{1}, \mathrm{D}_{1}$ and $\left.\mathrm{E}_{1}\right)$ and three from cultivar IAC 503 (lots $A_{2}, C_{2}$ and $E_{2}$ ), were used. These cultivars were chosen because they were representative of those in approximately $90 \%$ of the area planted with peanuts in the State of São Paulo at the time the study was conducted.

Samples were taken by collecting $20 \mathrm{~kg}$ of peanuts in their pods from each lot, following the principles described in the Brazilian Seed Rules (Brasil 2009b) for obtaining representative samples. The collections were performed at the beginning and end of a six-month period of storage in seed processing plants located in Campinas (A), Jaboticabal (B and C), Marília (D) and Sertãozinho (E) in the State of São Paulo, Brazil. At each sampling time, the samples were shelled and divided into two subsamples. One of the subsamples was treated with Maxim XL® (fludioxonil + metalaxyl), a systemic and contact wide-spectrum fungicide, at the highest commercially recommended dose: $300 \mathrm{~mL}$ per $100 \cdot \mathrm{kg}^{-1}$ of peanut seeds. The other subsample was not treated. The selected dose is indicated for the control of Rhizopus spp. but it also controls the other pathogenic fungi that occur in these seeds. This treatment was used as an additional tool to obtain data on the germination rate for these seeds in the tests with and without fungal activity to determine whether the fungi negatively affect the germination process.

Each subsample underwent the following tests, performed with 100 or 120 seeds by subsample. As the seeds should be shelled manually in order to avoid mechanical injuries and this operation is time consuming, these were the maximum amount of seeds that might be provided by subsample for each test, considering that all the tests should be carried out in the shortest period after each sampling time to avoid possible changes in the quality of seeds that would be assessed.

Moisture content - measured using the oven-drying method at $105 \pm 3{ }^{\circ} \mathrm{C}$ for $24 \mathrm{~h}$ (Brasil 2009b) and four replicates of 25 untreated or treated seeds each. The results, expressed in percentages, were calculated based on the wet weight.

Infested seeds - Corcyra cephalonica - conducted with four replicates, each with 25 untreated seeds, which were examined dry to identify those with insect exit holes. The seeds with exit holes were counted, recorded and then discarded. The remaining seeds from each replicate were submersed in water for $24 \mathrm{~h}$ to soften them and then cut to analyze their internal structures. The number of seeds with insect eggs, larvae, pupae or adults was recorded. This value was added to the number of perforated seeds to obtain the 
total number of infested seeds. The results were expressed as percentages (Brasil 2009b).

Cyrtomenus mirabilis - conducted with four replicates, each with 25 untreated seeds that were immersed in water for $24 \mathrm{~h}$ to remove the seed coat. The number of seeds with visible holes made by burrower bugs was determined, and the results were expressed as percentages of the total number of seeds in the sample.

Seed health test - performed using the blotter test with four replicates and 30 untreated or treated seeds per replicate that were spread on three layers of filter paper soaked in distilled water and placed in Petri dishes. Seeds were then incubated for seven days at $20 \pm 2{ }^{\circ} \mathrm{C}$ under a 12 -hour light/dark cycle using white light. While the Seed Health Analysis Manual (Brasil 2009a) determines a period of 10 days for incubating seeds treated with fungicide in this test if the objective is to market the analyzed seeds, it was chosen to carry it out also with seven days of incubation, due to the evident growth of Rhizopus spp. on the treated seeds at that time. These fungi could develop rapidly by extending the test, covering the entire Petri dishes and preventing the identification of other fungi (Moraes and Mariotto 1985), which were also grown on the seeds. After the incubation, the microorganisms were visualized under a stereomicroscope and identified based on the morphological characteristics of the fungal structures observed in the seeds or, when in doubt, by preparing slides for an examination of the fungal structures under an optical microscope and comparing their characteristics with those in the literature (Barnett and Hunter 2006). The fungal incidence data for the analyzed seeds were expressed as percentages.

Germination test - conducted with four replicates of 25 untreated or treated seeds per replicate that were spread on germitest paper towels previously soaked with a volume of water equivalent to 2.5 times the weight of the dry substrate. The towels were configured in rolls and kept in a standard germinator with alternating temperatures between 20 and $30^{\circ} \mathrm{C}$. Counts were performed at five and 10 days after sowing to determine the percentage of normal and infected seedlings or dead seeds (Brasil 2009b).

Test of seedling emergence in sand - performed in a greenhouse with four replicates of 25 untreated or treated seeds per replicate that were sown in plastic trays with sand moistened to $60 \%$ of its water-holding capacity. An analysis of emergence was performed at 10 and 15 days after the test began, when the seedlings had expanded embryonic leaves (Brasil 2009b).

Accelerated aging test - performed with four replicates of 25 untreated or treated seeds per replicate that were spread in a single layer on a wire mesh tray attached to plastic boxes $(11 \times 11 \times 3 \mathrm{~cm})$. Then, $40 \mathrm{~mL}$ of water was added to the bottom of each box, which was sealed and maintained at $42^{\circ} \mathrm{C}$ for $72 \mathrm{~h}$. The seeds then underwent a germination test, as previously described (Marcos Filho 1999).

A completely randomized experimental design was used with a $13 \times 2$ (13 lots and two levels of fungicidal treatment) factorial arrangement. For the infested seeds, only the lots were compared because the samples were not treated with fungicide. An arc $\sin \sqrt{\times 100^{-1}}$ transformation was applied to the results expressed as percentages. The analysis of variance and F-test were used for data analysis, and means were compared by Tukey's test at a $5 \%$ significance level, using the statistical program SISVAR (Ferreira 2014). The Pearson correlation test ( $\mathrm{r}$ ) was also used for data analysis $(\mathrm{p}<0.05$ or 0.01$)$.

\section{RESULTS AND DISCUSSION}

At the beginning of storage, the water content of the seeds was between 5.3 and $6.3 \%$, below the limit considered adequate for peanut seed storage, which should range between 8 and 10\% (Nakagawa and Rosolem 2011). Although it contributes to the preservation of seed quality, low water contents facilitate damage and cracks in the pods and seeds, thus accelerating the deterioration process and promoting attacks by insect pests and fungi.

Most of the reported damage caused by insects was attributable to C. mirabilis, which occurs in the field, and to C. cephalonica, which is present during storage (Table 1). The predominant fungi associated with peanut seeds were Aspergillus spp., Fusarium sp., Penicillium spp. and Rhizopus sp. (Tables 2, 3). In certain lots, Alternaria alternata (Fr.) Keissler, Rhizoctonia solani Kühn and Chaetomium sp., Cladosporium sp., Drechslera sp. and Phoma sp. were sporadically found. These fungi contaminate the seeds, as exposed to improper storage conditions, and may decrease their viability.

The minimum germination rate for commercial peanut seeds in the State of São Paulo is 60\% (Brasil 2013). In lots $A_{1}, B_{6}, C_{1}, D_{1}, E_{1}$ and $E_{2}$, the seeds had low germination rates, ranging from 6 to $56 \%$. These values may have been affected 
by the abundance of fungi detected in the seeds. Lots $A_{1}, C_{1}$, $\mathrm{D}_{1}$ and $\mathrm{E}_{1}$, with or without fungicidal treatment, had a higher

Table 1. Mean values (\%) for damage caused by Cyrtomenus mirabilis and Corcyra cephalonica to peanut seeds obtained from five seed processing plants in the State of São Paulo and sampled at the beginning and end of a six-month storage period.

\begin{tabular}{|c|c|c|c|c|}
\hline \multirow{2}{*}{ Lot } & \multicolumn{2}{|c|}{ Cyrtomenus mirabilis } & \multicolumn{2}{|c|}{ Corcyra cephalonica } \\
\hline & Beginning & End & Beginning & End \\
\hline$A_{1}$ & $17 a$ & $20 a$ & $11 a$ & $24 a$ \\
\hline $\mathrm{A}_{2}$ & $10 a b$ & $8 \mathrm{bc}$ & $4 \mathrm{bcd}$ & $11 a b$ \\
\hline $\mathrm{B}_{1}$ & $3 \mathrm{bc}$ & $6 \mathrm{bc}$ & $4 \mathrm{bcd}$ & $11 a b$ \\
\hline $\mathrm{B}_{2}$ & $1 \mathrm{c}$ & $2 \mathrm{bc}$ & $1 d$ & $5 b$ \\
\hline $\mathrm{B}_{3}$ & $3 \mathrm{bc}$ & $8 \mathrm{bc}$ & $3 \mathrm{~cd}$ & $9 \mathrm{~b}$ \\
\hline $\mathrm{B}_{4}$ & $5 \mathrm{bc}$ & $3 \mathrm{bc}$ & $3 \mathrm{~cd}$ & $7 b$ \\
\hline $\mathrm{B}_{5}$ & $2 c$ & $9 \mathrm{bc}$ & $5 \mathrm{bc}$ & $13 a b$ \\
\hline $\mathrm{B}_{6}$ & $2 c$ & $8 \mathrm{bc}$ & $8 a b$ & $12 a b$ \\
\hline $\mathrm{C}_{1}$ & $7 \mathrm{bc}$ & $11 \mathrm{bc}$ & $6 \mathrm{bc}$ & $10 a b$ \\
\hline $\mathrm{C}_{2}$ & $6 \mathrm{bc}$ & $7 \mathrm{bc}$ & $6 \mathrm{bc}$ & $8 b$ \\
\hline $\mathrm{D}_{1}$ & $1 \mathrm{c}$ & $1 \mathrm{c}$ & $4 \mathrm{bcd}$ & $10 a b$ \\
\hline $\mathrm{E}_{1}$ & $3 \mathrm{bc}$ & $1 \mathrm{c}$ & $4 \mathrm{bcd}$ & $11 a b$ \\
\hline $\mathrm{E}_{2}$ & $2 c$ & $4 \mathrm{bc}$ & $6 \mathrm{bc}$ & $11 a b$ \\
\hline CV (\%) & 33.30 & 27.57 & 17.28 & 21.96 \\
\hline
\end{tabular}

Means within a column followed by the same letter are not significantly different by Tukey's test $(p<0.05)$. percentage of infected seedlings ( 36 to $58 \%$ ), when compared with the other lots (Table 4). Marchi et al. (2011) and Santos et al. (2013) also reported that peanut seeds frequently have unsatisfactory germination rates for this reason.

The low germination rates in lots $A_{1}, C_{1}, D_{1}$ and $E_{1}$ (Table 4) were also confirmed by the seedling emergence in sand and accelerated aging tests (Table 5). However, the germination rate of the seeds in the test of seedling emergence in sand was higher than it was in the germination test. These results are consistent with other studies performed with peanut (Bittencourt et al. 2007) and soybean seeds (Schuab et al. 2006). The humidity and temperature conditions in the germination test and the proximity between seeds on the toweling rolls may create a favorable "microclimate" for the proliferation of several microorganisms, thus negatively affecting seed germination.

The analyses of the effect of the incidence of microorganisms on peanut seed germination and vigor showed negative and highly significant correlations between the Aspergillus spp. fungi and the results of the tests on germination $(-0.82)$, accelerated aging $(-0.82)$ and seedling emergence in sand $(-0.85)$. The control of fungi of the genus Aspergillus is important for increasing the germination and vigor rates of peanut seeds and also because Aspergillus is the principal genus involved in aflatoxin production (Smith and Ross 1991).

Table 2. Mean values (\%) for the incidence of Aspergillus spp. and Fusarium sp. fungi obtained from peanuts treated or untreated with fungicide ${ }^{(1)}$ and the percent reduction with treatment.

\begin{tabular}{|c|c|c|c|c|c|c|c|c|c|c|c|c|}
\hline \multirow{3}{*}{ Lot } & \multicolumn{6}{|c|}{ Beginning of storage } & \multicolumn{6}{|c|}{ After six months of storage } \\
\hline & \multicolumn{3}{|c|}{ Aspergillus spp. } & \multicolumn{3}{|c|}{ Fusarium sp. } & \multicolumn{3}{|c|}{ Aspergillus spp. } & \multicolumn{3}{|c|}{ Fusarium sp. } \\
\hline & UT & $\mathbf{T}$ & $\% R$ & UT & $\mathbf{T}$ & $\% R$ & UT & $\mathbf{T}$ & $\% R$ & UT & $\mathbf{T}$ & $\% R$ \\
\hline$A_{1}$ & $53 \mathrm{Aa}$ & $23 \mathrm{Ab}$ & 57 & $69 \mathrm{Aa}$ & $32 \mathrm{Ab}$ & 54 & $51 \mathrm{Aa}$ & $37 \mathrm{ABa}$ & 27 & $26 \mathrm{ABa}$ & $14 \mathrm{ABb}$ & 46 \\
\hline $\mathrm{A}_{2}$ & $18 \mathrm{BCa}$ & $11 \mathrm{ABCa}$ & 39 & $8 \mathrm{CDa}$ & $3 \mathrm{CDa}$ & 62 & $37 \mathrm{ABa}$ & $30 \mathrm{ABCa}$ & 19 & $6 \mathrm{DEa}$ & $3 \mathrm{BCa}$ & 50 \\
\hline $\mathrm{B}_{1}$ & $12 \mathrm{Ca}$ & $3 \mathrm{CDb}$ & 75 & $5 \mathrm{Da}$ & $0 \mathrm{Da}$ & 100 & $28 \mathrm{ABa}$ & $14 \mathrm{BCb}$ & 50 & 3 DEa & $0 \mathrm{Ca}$ & 100 \\
\hline $\mathrm{B}_{2}$ & $8 \mathrm{Ca}$ & $1 \mathrm{Db}$ & 88 & $31 \mathrm{BCa}$ & $15 \mathrm{ABCb}$ & 52 & $25 \mathrm{ABa}$ & $13 \mathrm{BCa}$ & 48 & 13 CDEa & $11 \mathrm{ABCa}$ & 15 \\
\hline $\mathrm{B}_{3}$ & $7 \mathrm{Ca}$ & $0 \mathrm{Db}$ & 100 & $4 \mathrm{Da}$ & $0 \mathrm{Da}$ & 100 & $31 \mathrm{ABa}$ & $22 \mathrm{ABCa}$ & 29 & $1 \mathrm{Ea}$ & $\mathrm{OCa}$ & 100 \\
\hline $\mathrm{B}_{4}$ & $9 \mathrm{Ca}$ & $7 \mathrm{BCDa}$ & 22 & $45 \mathrm{ABCa}$ & $7 \mathrm{BCDb}$ & 84 & $47 \mathrm{Aa}$ & $21 \mathrm{ABCb}$ & 55 & 6 DEa & $2 \mathrm{BCa}$ & 67 \\
\hline$B_{5}$ & $21 \mathrm{BCa}$ & $3 \mathrm{CDb}$ & 86 & $46 \mathrm{ABCa}$ & $3 \mathrm{CDb}$ & 93 & $43 \mathrm{Aa}$ & $46 \mathrm{Aa}$ & -7 & $1 \mathrm{Ea}$ & $\mathrm{OCa}$ & 100 \\
\hline $\mathrm{B}_{6}$ & $9 \mathrm{Ca}$ & $6 \mathrm{BCDa}$ & 33 & $70 \mathrm{Aa}$ & $26 \mathrm{Ab}$ & 63 & $38 \mathrm{ABa}$ & $10 \mathrm{Cb}$ & 74 & $14 \mathrm{BCDa}$ & $13 \mathrm{Aba}$ & 7 \\
\hline$C_{1}$ & $43 \mathrm{ABa}$ & $22 \mathrm{ABb}$ & 49 & $59 \mathrm{ABa}$ & $23 \mathrm{Ab}$ & 61 & $45 \mathrm{Aa}$ & $15 \mathrm{BCb}$ & 67 & 12 CDEa & $5 \mathrm{BCa}$ & 58 \\
\hline$C_{2}$ & $12 \mathrm{Ca}$ & $2 \mathrm{Db}$ & 83 & $46 \mathrm{ABCa}$ & $13 \mathrm{ABCb}$ & 72 & $14 \mathrm{Ba}$ & $8 \mathrm{Cb}$ & 43 & $22 \mathrm{ABCa}$ & $19 \mathrm{Aa}$ & 14 \\
\hline $\mathrm{D}_{1}$ & $51 \mathrm{Aa}$ & $28 \mathrm{Ab}$ & 47 & $46 \mathrm{ABCa}$ & $16 \mathrm{ABb}$ & 65 & $55 \mathrm{Aa}$ & $20 \mathrm{ABCb}$ & 64 & $31 \mathrm{Aa}$ & $12 \mathrm{ABCb}$ & 61 \\
\hline $\mathrm{E}_{1}$ & $13 \mathrm{Ca}$ & $3 \mathrm{CDb}$ & 77 & $23 \mathrm{BCa}$ & $3 \mathrm{CDb}$ & 87 & $25 \mathrm{ABa}$ & $17 \mathrm{BCa}$ & 32 & 12 CDEa & $6 \mathrm{BCa}$ & 50 \\
\hline$E_{2}$ & $18 \mathrm{BCa}$ & $1 \mathrm{Db}$ & 94 & $10 \mathrm{CDa}$ & $2 \mathrm{Db}$ & 89 & $34 \mathrm{ABa}$ & $30 \mathrm{ABCb}$ & 12 & $4 \mathrm{DEa}$ & $1 \mathrm{Ca}$ & 75 \\
\hline CV (\%) & & 26.95 & & & 34.73 & & & 19.42 & & & 27.08 & \\
\hline
\end{tabular}

The peanuts were obtained from five seed processing plants in the State of São Paulo and sampled at the beginning and end of a six-month storage period. Means followed by the same uppercase letter in a column and lowercase letter in a row are not different from each other $(p<0.05)$. ${ }^{(1)}$ Fludioxonil + metalaxyl at a dose of $300 \mathrm{~mL}$ of commercial product per $100 \mathrm{~kg}$ of seeds. UT = Untreated; $\mathrm{T}=$ Treated; \% $\mathrm{R}=$ Percent reduction. 
Table 3. Mean values (\%) for the incidence of Penicillium spp. and Rhizopus sp. fungi in peanuts treated or untreated with fungicide ${ }^{(1)}$ and the percent reduction with treatment

\begin{tabular}{|c|c|c|c|c|c|c|c|c|c|c|c|c|}
\hline \multirow{3}{*}{ Lot } & \multicolumn{6}{|c|}{ Beginning of storage } & \multicolumn{6}{|c|}{ After six months of storage } \\
\hline & \multicolumn{3}{|c|}{ Penicillium spp. } & \multicolumn{3}{|c|}{ Rhizopus sp. } & \multicolumn{3}{|c|}{ Penicillium spp. } & \multicolumn{3}{|c|}{ Rhizopus sp. } \\
\hline & UT & $\mathbf{T}$ & $\% R$ & UT & $\mathbf{T}$ & $\% R$ & UT & $\mathbf{T}$ & $\% \mathbf{R}$ & UT & $\mathbf{T}$ & $\% R$ \\
\hline$A_{1}$ & $32 \mathrm{BCa}$ & $13 \mathrm{CDb}$ & 59 & $25 \mathrm{ABCa}$ & $14 \mathrm{Aba}$ & 44 & $82 \mathrm{Aa}$ & $61 \mathrm{Aa}$ & 26 & $70 \mathrm{Aa}$ & $53 \mathrm{Aa}$ & 24 \\
\hline $\mathrm{A}_{2}$ & $58 \mathrm{ABa}$ & $16 \mathrm{CDb}$ & 72 & $30 \mathrm{ABa}$ & $13 \mathrm{ABb}$ & 57 & $71 \mathrm{Aa}$ & $57 \mathrm{Aa}$ & 20 & $47 \mathrm{ABa}$ & $37 \mathrm{ABa}$ & 21 \\
\hline $\mathrm{B}_{1}$ & $26 \mathrm{CDa}$ & $5 \mathrm{DEb}$ & 81 & $31 \mathrm{ABa}$ & $25 \mathrm{Aa}$ & 19 & $31 \mathrm{DEa}$ & $32 \mathrm{BCa}$ & -3 & $34 \mathrm{ABCa}$ & $30 \mathrm{ABa}$ & 12 \\
\hline $\mathrm{B}_{2}$ & $8 \mathrm{Da}$ & $5 \mathrm{DEa}$ & 38 & $25 \mathrm{ABCa}$ & $10 \mathrm{ABb}$ & 60 & $13 \mathrm{Ea}$ & $8 \mathrm{~Eb}$ & 38 & $23 \mathrm{BCa}$ & $14 \mathrm{BCDa}$ & 39 \\
\hline $\mathrm{B}_{3}$ & $20 \mathrm{CDa}$ & $4 \mathrm{~Eb}$ & 80 & $30 \mathrm{ABa}$ & $8 \mathrm{ABCb}$ & 73 & $25 \mathrm{DEa}$ & $13 \mathrm{DEb}$ & 48 & $10 \mathrm{Ca}$ & $3 \mathrm{DEb}$ & 70 \\
\hline $\mathrm{B}_{4}$ & $20 \mathrm{CDa}$ & $21 \mathrm{BCa}$ & -5 & $32 \mathrm{Aa}$ & $4 \mathrm{BCb}$ & 88 & 36 CDEa & $22 \mathrm{CDb}$ & 39 & $18 \mathrm{BCa}$ & $7 \mathrm{CDEb}$ & 61 \\
\hline $\mathrm{B}_{5}$ & $26 \mathrm{CDa}$ & $13 \mathrm{CDa}$ & 50 & $27 \mathrm{ABa}$ & $2 \mathrm{Cb}$ & 93 & $43 \mathrm{BCa}$ & $40 \mathrm{ABCa}$ & 7 & $31 \mathrm{ABCa}$ & 9 CDEb & 71 \\
\hline $\mathrm{B}_{6}$ & $60 \mathrm{ABa}$ & $23 \mathrm{BCb}$ & 62 & $38 \mathrm{Aa}$ & $19 A b$ & 50 & $61 \mathrm{ABCa}$ & $33 \mathrm{BCb}$ & 46 & $48 \mathrm{ABa}$ & $20 \mathrm{BCDb}$ & 58 \\
\hline$C_{1}$ & $69 \mathrm{Aa}$ & $10 \mathrm{CDEb}$ & 86 & $34 \mathrm{Aa}$ & $11 \mathrm{ABb}$ & 68 & $68 \mathrm{ABa}$ & $36 \mathrm{BCb}$ & 47 & $43 \mathrm{ABa}$ & $23 \mathrm{ABCb}$ & 47 \\
\hline $\mathrm{C}_{2}$ & $66 \mathrm{ABa}$ & $13 \mathrm{CDb}$ & 80 & $30 \mathrm{ABa}$ & $13 \mathrm{ABb}$ & 57 & $74 \mathrm{Aa}$ & $25 \mathrm{CDb}$ & 66 & $23 \mathrm{BCa}$ & $2 \mathrm{~Eb}$ & 91 \\
\hline $\mathrm{D}_{1}$ & $75 \mathrm{Aa}$ & $26 \mathrm{ABCb}$ & 65 & $11 \mathrm{BCa}$ & $14 \mathrm{Aba}$ & -27 & $78 \mathrm{Aa}$ & $45 \mathrm{ABCb}$ & 42 & $29 \mathrm{BCa}$ & 8 CDEb & 72 \\
\hline $\mathrm{E}_{1}$ & $67 \mathrm{ABa}$ & $34 \mathrm{ABb}$ & 49 & $8 \mathrm{Ca}$ & $2 \mathrm{Cb}$ & 75 & $80 \mathrm{Aa}$ & $50 \mathrm{ABb}$ & 38 & $50 \mathrm{ABa}$ & $31 \mathrm{ABb}$ & 38 \\
\hline$E_{2}$ & $56 \mathrm{ABa}$ & $41 \mathrm{Aa}$ & 27 & $27 \mathrm{ABa}$ & $18 \mathrm{Aba}$ & 33 & $45 \mathrm{BCa}$ & $34 \mathrm{BCa}$ & 24 & $22 \mathrm{BCa}$ & 7 CDEb & 68 \\
\hline CV (\%) & & 21.89 & & & 24.99 & & & 14.25 & & & 25.44 & \\
\hline
\end{tabular}

The peanuts were obtained from five seed processing plants in the State of São Paulo and sampled at the beginning and end of a six-month storage period Means followed by the same uppercase letter in a column and lowercase letter in a row are not different from each other $(p<0.05)$. ${ }^{(1)}$ Fludioxonil + metalaxyl at a dose of $300 \mathrm{~mL}$ of commercial product per $100 \mathrm{~kg}$ of seeds. UT = Untreated; $\mathrm{T}=$ Treated; $\% \mathrm{R}=$ Percent reduction.

Table 4. Mean values (\%) for normal seedlings, infected seedlings and dead seeds measured in a germination test of peanut seeds treated or untreated with fungicide ${ }^{(1)}$

\begin{tabular}{|c|c|c|c|c|c|c|c|c|c|c|c|c|}
\hline \multirow{3}{*}{ Lot } & \multicolumn{6}{|c|}{ Beginning of storage } & \multicolumn{6}{|c|}{ After six months of storage } \\
\hline & \multicolumn{2}{|c|}{ NS } & \multicolumn{2}{|c|}{ IS } & \multicolumn{2}{|c|}{ DS } & \multicolumn{2}{|c|}{ NS } & \multicolumn{2}{|c|}{ IS } & \multicolumn{2}{|c|}{ DS } \\
\hline & UT & $\mathbf{T}$ & UT & $\mathbf{T}$ & UT & $\mathbf{T}$ & UT & $\mathbf{T}$ & UT & $\mathbf{T}$ & UT & $\mathbf{T}$ \\
\hline$A_{1}$ & $6 \mathrm{Db}$ & $30 \mathrm{Ca}$ & $41 \mathrm{ABa}$ & $42 \mathrm{Aa}$ & $50 \mathrm{Aa}$ & $26 \mathrm{Ab}$ & $4 \mathrm{~Eb}$ & $21 \mathrm{Da}$ & $50 \mathrm{Aa}$ & $30 \mathrm{ABb}$ & $46 \mathrm{Aa}$ & $48 \mathrm{Aa}$ \\
\hline $\mathrm{A}_{2}$ & $75 \mathrm{Aa}$ & $88 \mathrm{Aa}$ & $16 \mathrm{Ca}$ & $6 \mathrm{Cb}$ & $9 \mathrm{BCa}$ & $3 \mathrm{CDb}$ & $76 \mathrm{ABCb}$ & $92 \mathrm{Aa}$ & $6 \mathrm{DEa}$ & 3 Ea & $14 \mathrm{Ba}$ & $5 \mathrm{BCDb}$ \\
\hline $\mathrm{B}_{1}$ & $86 \mathrm{Aa}$ & $87 \mathrm{ABa}$ & $11 \mathrm{Ca}$ & $7 \mathrm{BCa}$ & $2 \mathrm{CDb}$ & $6 \mathrm{BCa}$ & $73 \mathrm{ABCb}$ & $93 \mathrm{Aa}$ & $23 \mathrm{BCa}$ & $2 \mathrm{~Eb}$ & $4 \mathrm{BCDa}$ & $4 \mathrm{BCDa}$ \\
\hline $\mathrm{B}_{2}$ & $88 \mathrm{Aa}$ & $91 \mathrm{Aa}$ & $10 \mathrm{Ca}$ & $8 \mathrm{BCa}$ & $2 \mathrm{CDa}$ & $1 \mathrm{Da}$ & $73 \mathrm{ABCa}$ & $78 \mathrm{ABa}$ & 11 CDEa & $3 \mathrm{~Eb}$ & $13 \mathrm{Ba}$ & $9 \mathrm{BCa}$ \\
\hline $\mathrm{B}_{3}$ & $88 \mathrm{Aa}$ & $95 \mathrm{Aa}$ & $8 \mathrm{CDa}$ & $2 \mathrm{Cb}$ & $0 \mathrm{Da}$ & $0 \mathrm{Da}$ & $87 \mathrm{Aa}$ & $95 \mathrm{Aa}$ & 5 Ea & 2 Ea & $8 \mathrm{BCa}$ & $1 \mathrm{CDb}$ \\
\hline $\mathrm{B}_{4}$ & $89 \mathrm{Aa}$ & $92 \mathrm{Aa}$ & $7 \mathrm{Da}$ & $4 \mathrm{Ca}$ & $4 \mathrm{Ca}$ & $3 \mathrm{CDa}$ & $96 \mathrm{Aa}$ & $96 \mathrm{Aa}$ & $4 \mathrm{Ea}$ & $2 \mathrm{Ea}$ & $0 \mathrm{Da}$ & $0 \mathrm{Da}$ \\
\hline $\mathrm{B}_{5}$ & $66 \mathrm{Aa}$ & $80 \mathrm{ABa}$ & $22 \mathrm{Ba}$ & $18 \mathrm{Ba}$ & $8 \mathrm{BCa}$ & $2 \mathrm{CDb}$ & $80 \mathrm{Aba}$ & $88 \mathrm{Aa}$ & $8 \mathrm{DEa}$ & $4 \mathrm{DEa}$ & $12 \mathrm{Ba}$ & $8 \mathrm{BCa}$ \\
\hline $\mathrm{B}_{6}$ & $56 \mathrm{Ba}$ & $78 \mathrm{ABa}$ & $20 \mathrm{BCa}$ & $4 \mathrm{Cb}$ & $18 \mathrm{Ba}$ & $13 \mathrm{ABa}$ & 80 Aba & $91 \mathrm{Aa}$ & $9 \mathrm{DEa}$ & 9 CDEa & $11 \mathrm{Ba}$ & $0 \mathrm{Db}$ \\
\hline $\mathrm{C}_{1}$ & $28 \mathrm{Cb}$ & $44 \mathrm{BCa}$ & $55 \mathrm{Aa}$ & $42 \mathrm{Aa}$ & $17 \mathrm{Ba}$ & $14 \mathrm{ABa}$ & $59 \mathrm{BCb}$ & $75 \mathrm{ABa}$ & $40 \mathrm{ABa}$ & $25 \mathrm{ABCb}$ & $1 \mathrm{CDa}$ & $0 \mathrm{Da}$ \\
\hline $\mathrm{C}_{2}$ & $59 \mathrm{ABa}$ & $78 \mathrm{ABa}$ & $20 \mathrm{BCa}$ & $4 \mathrm{Cb}$ & $5 \mathrm{Ca}$ & $2 \mathrm{CDb}$ & $64 \mathrm{ABCa}$ & $72 \mathrm{ABa}$ & $21 \mathrm{BCDa}$ & $17 \mathrm{BCDa}$ & $15 \mathrm{Ba}$ & $8 \mathrm{BCa}$ \\
\hline $\mathrm{D}_{1}$ & $28 \mathrm{Cb}$ & $44 \mathrm{BCa}$ & $58 \mathrm{Aa}$ & $52 \mathrm{Aa}$ & $12 \mathrm{BCa}$ & $4 \mathrm{BCb}$ & $33 \mathrm{Da}$ & $39 \mathrm{Ca}$ & $52 \mathrm{Aa}$ & $50 \mathrm{Aa}$ & $15 \mathrm{Ba}$ & $10 \mathrm{ABa}$ \\
\hline $\mathrm{E}_{1}$ & $33 \mathrm{BCa}$ & $44 \mathrm{BCa}$ & $45 \mathrm{Aa}$ & $47 \mathrm{Aa}$ & $20 \mathrm{Ba}$ & $8 \mathrm{BCb}$ & $58 \mathrm{BCa}$ & $64 \mathrm{Ba}$ & $36 \mathrm{ABa}$ & $15 \mathrm{BCDb}$ & $6 \mathrm{BCD} b$ & $21 \mathrm{Aa}$ \\
\hline$E_{2}$ & $54 \mathrm{Bb}$ & $92 \mathrm{Aa}$ & $36 \mathrm{ABa}$ & $2 \mathrm{Cb}$ & $0 \mathrm{Da}$ & $0 \mathrm{Da}$ & $55 \mathrm{Cb}$ & $77 \mathrm{ABa}$ & $26 \mathrm{ABCa}$ & $6 \mathrm{DEb}$ & $16 \mathrm{Ba}$ & $15 \mathrm{ABa}$ \\
\hline CV (\%) & \multicolumn{2}{|c|}{12.50} & \multicolumn{2}{|c|}{19.12} & \multicolumn{2}{|c|}{24.05} & \multicolumn{2}{|c|}{6.57} & \multicolumn{2}{|c|}{23.21} & \multicolumn{2}{|c|}{28.23} \\
\hline
\end{tabular}

The peanuts were obtained from five seed processing plants in the State of São Paulo and sampled at the beginning and end of a six-month storage period. Means followed by the same uppercase letter in a column or lowercase letter in a row are not different from each other ( $p<0.05)$. (1) Fludioxonil + metalaxyl at a dose of $300 \mathrm{~mL}$ of commercial product per $100 \mathrm{~kg}$ of seeds. NS = Normal seedlings; IS = Infected seedlings; DS = Dead seeds; UT = Untreated; T = Treated. 
The Fusarium sp. and Penicillium spp. fungi also exhibited interactions unfavorable for peanut seed germination. In untreated seeds, the Penicillium spp. had a negative and significant correlation with normal seedlings $(-0.61)$ and a positive and highly significant correlation with infected seedlings (0.71).

Although treatment with fludioxonil + metalaxyl did not eradicate the fungi present in the seeds, their incidence was reduced, with a consequent increase, in absolute values, in the germination performance and vigor of the analyzed lots as well as a reduced percentage of infected seedlings and dead seeds (Tables 4 and 5). These results confirm that fungi reduce the physiological quality, interfering in the germination process of peanut seeds. In addition to fungi, other factors may prevent the production of normal seedlings, such as infestation by insects and low physiological quality of the seed itself. The presence of pest insects negatively affected germination and vigor. $C$. mirabilis was positively and highly significantly correlated with dead seeds $(0.70)$. The same relationship was found for C. cephalonica (0.78). Therefore, the incidence of these insects decreased the germination rate while increasing the percentage of dead seeds.

There were also significant and negative correlations between infestation with C. mirabilis or C. cephalonica and the emergence of seedlings in sand $(-0.71$ or -0.72 , respectively) and the accelerated aging results $(-0.66$ or -0.80 , respectively), proving the detrimental effects of these insects on the physiological quality of the seeds. Importantly, there was a significant and positive correlation between C. mirabilis and C. cephalonica infestations (0.63) and between C. cephalonica and Fusarium sp. infestations (0.61), indicating for each pair of species that both occur together and cause deterioration of peanut seeds.

After six months of storage, the water content of the peanut seeds ranged from 5.4 to $6.6 \%$ because of the relative humidity of the air and temperature of the warehouses. These levels are considered adequate for seed preservation but may render seeds more susceptible to mechanical injury, especially during shelling operations (Baskin and Delouche 1971). Because of their relatively exposed embryonic axis and thin seed coat, the seeds are very vulnerable to mechanical damage.

During storage, the presence of damage in the dry pods increased the percentage of seeds attacked by C. cephalonica (Table 1). The attack by this insect was significantly negatively correlated with normal seedlings $(-0.70)$, with the seedling emergence in sand $(-0.57)$ and with the accelerated aging $(-0.64)$ results and was significantly positively correlated

Table 5. Mean normal seedlings (\%) for peanut seeds treated or untreated with fungicide ${ }^{(1)}$ in tests measuring seedling emergence in sand and accelerated aging.

\begin{tabular}{|c|c|c|c|c|c|c|c|c|}
\hline \multirow{3}{*}{ Lot } & \multicolumn{4}{|c|}{ Beginning of storage } & \multicolumn{4}{|c|}{ After six months of storage } \\
\hline & \multicolumn{2}{|c|}{ SES } & \multicolumn{2}{|c|}{ AA } & \multicolumn{2}{|c|}{ SES } & \multicolumn{2}{|c|}{ AA } \\
\hline & UT & $\mathbf{T}$ & UT & $\mathbf{T}$ & UT & $\mathbf{T}$ & UT & $\mathbf{T}$ \\
\hline$A_{1}$ & $24 \mathrm{Db}$ & $56 \mathrm{Da}$ & $4 \mathrm{Fb}$ & $29 \mathrm{Da}$ & $31 \mathrm{~Eb}$ & $43 \mathrm{Da}$ & $18 \mathrm{Db}$ & $34 \mathrm{Ba}$ \\
\hline$A_{2}$ & $79 \mathrm{ABa}$ & $87 \mathrm{BCa}$ & $56 \mathrm{CDb}$ & $87 \mathrm{ABa}$ & $88 \mathrm{ABa}$ & $95 \mathrm{Aa}$ & $56 \mathrm{BCb}$ & $80 \mathrm{Aa}$ \\
\hline $\mathrm{B}_{1}$ & $88 \mathrm{ABa}$ & $92 \mathrm{ABa}$ & $81 \mathrm{ABa}$ & $88 \mathrm{ABa}$ & $80 \mathrm{BCb}$ & $96 \mathrm{Aa}$ & $73 \mathrm{Aba}$ & $86 \mathrm{Aa}$ \\
\hline $\mathrm{B}_{2}$ & $81 \mathrm{ABb}$ & $94 \mathrm{ABa}$ & $83 \mathrm{ABa}$ & $92 \mathrm{ABa}$ & $75 \mathrm{CDa}$ & $77 \mathrm{Ca}$ & $75 \mathrm{Aba}$ & $74 \mathrm{Aa}$ \\
\hline $\mathrm{B}_{3}$ & $91 \mathrm{Aa}$ & $96 \mathrm{ABa}$ & $88 \mathrm{Aa}$ & $98 \mathrm{Aa}$ & $91 \mathrm{ABa}$ & $94 \mathrm{ABa}$ & $80 \mathrm{Aa}$ & $91 \mathrm{Aa}$ \\
\hline $\mathrm{B}_{4}$ & $91 \mathrm{Aa}$ & $99 \mathrm{Aa}$ & $88 \mathrm{Aa}$ & $92 \mathrm{ABa}$ & $92 \mathrm{Aa}$ & $96 \mathrm{Aa}$ & $84 \mathrm{Aa}$ & $97 \mathrm{Aa}$ \\
\hline $\mathrm{B}_{5}$ & $88 \mathrm{ABa}$ & $96 \mathrm{ABa}$ & $80 \mathrm{ABa}$ & $87 \mathrm{ABa}$ & $90 \mathrm{ABa}$ & $92 \mathrm{BCa}$ & $79 \mathrm{Aa}$ & $88 \mathrm{Aa}$ \\
\hline $\mathrm{B}_{6}$ & $76 \mathrm{ABa}$ & $76 \mathrm{CDa}$ & $52 \mathrm{CDb}$ & $71 \mathrm{BCa}$ & $90 \mathrm{ABa}$ & $92 \mathrm{BCa}$ & $63 \mathrm{ABCb}$ & $90 \mathrm{Aa}$ \\
\hline $\mathrm{C}_{1}$ & $57 \mathrm{Cb}$ & $72 \mathrm{CDa}$ & $32 \mathrm{~Eb}$ & $52 \mathrm{Ca}$ & $72 \mathrm{CDa}$ & $81 \mathrm{BCa}$ & $63 \mathrm{ABCb}$ & $75 \mathrm{Aa}$ \\
\hline $\mathrm{C}_{2}$ & $70 \mathrm{BCa}$ & $77 \mathrm{BCa}$ & $68 \mathrm{BCb}$ & $83 \mathrm{ABa}$ & $83 \mathrm{BCa}$ & $87 \mathrm{BCa}$ & $56 \mathrm{BCb}$ & $75 \mathrm{Aa}$ \\
\hline $\mathrm{D}_{1}$ & $59 \mathrm{BCa}$ & $61 \mathrm{CDa}$ & $44 \mathrm{DEb}$ & $60 \mathrm{Ca}$ & $41 \mathrm{~Eb}$ & $53 \mathrm{Da}$ & $28 \mathrm{Db}$ & $44 \mathrm{Ba}$ \\
\hline $\mathrm{E}_{1}$ & $75 \mathrm{BCa}$ & $78 \mathrm{BCa}$ & $61 \mathrm{BCa}$ & $72 \mathrm{BCa}$ & $71 \mathrm{CDa}$ & $78 \mathrm{BCa}$ & $50 \mathrm{Cb}$ & $80 \mathrm{Aa}$ \\
\hline$E_{2}$ & $82 \mathrm{ABa}$ & $93 \mathrm{ABa}$ & $52 \mathrm{CDb}$ & $87 \mathrm{ABa}$ & $60 \mathrm{Db}$ & $80 \mathrm{BCa}$ & $51 \mathrm{Cb}$ & $89 \mathrm{Aa}$ \\
\hline CV (\%) & \multicolumn{2}{|c|}{5.18} & \multicolumn{2}{|c|}{7.06} & \multicolumn{2}{|c|}{3.93} & \multicolumn{2}{|c|}{6.57} \\
\hline
\end{tabular}

The peanuts were obtained from five seed processing plants in the State of São Paulo and sampled at the beginning and end of a six-month storage period. Means followed by the same uppercase letter in a column or by the same lowercase letter in a row are not different from each other ( $p<0.05)$. ${ }^{(1)}$ Fludioxonil + metalaxyl at a dose of $300 \mathrm{~mL}$ of commercial product per $100 \mathrm{~kg}$ of seeds. $\mathrm{SES}=$ Seedling emergence in sand; $A A=A c c e l e r a t e d$ aging; $U T=U n$ treated; $T=$ Treated. 
with dead seeds, directly interfering with seed quality. However, the percentage of seeds damaged by C. mirabilis did not change greatly after storage because infestation by this insect occurs in the field (Table 1).

The correlation between C. cephalonica and C. mirabilis infestations was positive and highly significant $(0.80)$. Furthermore, infestation by each of these insects was positively and significantly correlated with the incidence of fungi belonging to the genus Rhizopus (0.76 and 0.51 , respectively). These interactions may reduce the health of the stored peanut seeds.

After storage, the incidence of the storage fungi increased (Tables 2 and 3). The most common of these fungi were Aspergillus spp. and Penicillium spp., with percentages ranging from 14 to $55 \%$ and from 13 to $82 \%$, respectively. However, the survival of the Fusarium sp., which belongs to one of the major groups of pathogens associated with seed rot, decreased because species of this genus grow and are viable in seeds with high water content ( $90-95 \%)$, a state that is considered inadequate for orthodox seed preservation (Marcos Filho 2005).

After storage, the seeds retained their germination capacity, with certain lots showing a small increase in the percentage of normal seedlings (Table 4) because of the reduced incidence of field fungi, especially the Fusarium sp. (Table 2). This fungus, when found on the seeds, showed a highly significant and negative correlation $(-0.74)$ with normal seedlings and a positive correlation (0.71) with infected seedlings, reducing the germination rate. Lots $A_{1}, C_{1}, D_{1}, E_{1}$ and $E_{2}$ still had germination rates below the acceptable level (60\%; Table 4).

The results of the seedling emergence in sand and accelerated aging tests also showed that seed vigor was preserved during storage (Table 5). The seed performance was maintained, as shown by the germination test, and was also supported by the vigor tests, because a decrease in vigor precedes a reduction in germination rates during the deterioration process (Delouche and Baskin 1973). Storing the peanuts in their shells may have favored preservation because such storage protects the peanuts from insect and fungal attacks, as well as from unfavorable environmental factors.

In the untreated lots, negative and highly significant correlation coefficients were found for the relationships between the Fusarium sp. incidence and the results of the seedling emergence in sand $(-0.71)$ and the accelerated aging tests $(-0.79)$, showing the damaging effects of the fungus on seed vigor. In addition, there was a significant and negative correlation between the Penicillium spp. and the results of the germination $(-0.62)$ and accelerated aging $(-0.78)$ tests and a positive correlation of these fungi with infected seedlings (0.64), indicating that their presence affects the quality of the stored seeds, resulting in higher percentages of infected seedlings. The Rhizopus sp. incidence was also negatively and significantly correlated with normal seedlings $(-0.60)$ and the results of the accelerated aging $(-0.62)$ test. Overall, most of the fungi detected on the peanut seeds negatively affected the germination and vigor of the seeds.

Treatment with fludioxonil + metalaxyl improved seed performance (Tables 4 and 5). Marchi et al. (2011) also reported that a mixture of fludioxonil + metalaxyl, which has a wide spectrum of activity, effectively controlled storage fungi present in peanut seeds. For the treated seeds compared with the untreated ones, the percentage of normal seedlings in the germination, seedling emergence in sand and accelerated aging tests was higher, indicating the harmful action of the present fungi, which infect the peanut seeds during the process of germination and establishment of seedlings.

These results demonstrated the need for improved techniques for managing and controlling insects and fungi from seed maturation in the field through storage, even considering the protection provided by the pods, because the germination capacity maintained during this period could be improved only when the seeds were treated with fungicide.

These results also confirmed that the fungicide treatment of peanut seeds should be a mandatory practice and that the treatment can be performed immediately before planting, because the seed physiological quality remained practically unchanged, during a six-month storage period, despite an increase in storage fungi. In addition to reducing the inoculum potential, this procedure can also protect seeds and seedlings from pathogens in the seed itself, in the soil and in crop residues during the initial stages of germination and prevent the dissemination of pathogenic microorganisms to uncontaminated areas (Menten 1991).

\section{CONCLUSION}

The storage in the pods for six months before processing, adopted by São Paulo seed-producing companies, does not reduce germination capacity and vigor, even in lots with initial germination rates below $50 \%$, which may constitute 
the majority of available seeds, especially for years in which physiological maturity is reached during hot rainy periods.

The damage caused by C. mirabilis and C. cephalonica and the incidence of the Aspergillus spp., Fusarium sp.,
Penicillium spp. and Rhizopus sp. fungi that were observed from the beginning of the six-month post-harvest period are factors limiting the production of seed lots with adequate viability and vigor.

\section{REFERENCES}

Barnett, H. L. and Hunter, B. B. (2006). Illustrated genera of imperfect fungi. 4. ed. St.Paul: The American Phytopathological Society.

Baskin, C. C. and Delouche, J. C. (1971). Effect of mechanical shelling on storability of peanut (Arachis hypogaea L.) seed. Proceedings of the Association of Official Seed Analysts, 61, 78-84.

Bellettini, N. M. T., Endo, R. M., Miglioranza, E. and Santiago, D. C. (2005). Patogenicidade de fungos associados às sementes e plântulas de amendoim cv. Tatu. Semina: Ciências Agrárias, 26, 167-172. http://dx.doi.org/10.5433/1679-0359.2005v26n2p167.

Bittencourt, S. E. M., Menten, J. O. M., Araki, C. A. S., Moraes, M. H. D., Rugai, A. D., Dieguez, M. J. and Vieira, R. D. (2007). Eficiência do fungicida carboxin + thiram no tratamento de sementes de amendoim. Revista Brasileira de Sementes, 29, 214-222. http://dx.doi.org/10.1590/S0101-31222007000200028.

Borém, F. M, Resende, O., Machado, J. C, Fontenelle, I. M. R. and Souza, F. F. (2006). Controle de fungos presentes no ar e em sementes de feijão durante armazenamento. Revista Brasileira de Engenharia Agrícola e Ambiental, 10, 651-659. http://dx.doi. org/10.1590/S1415-43662006000300017.

Brasil (2009a). Ministério da Agricultura, Pecuária e Abastecimento. Manual de análise sanitária de sementes. Brasília: MAPA/ACS.

Brasil (2009b). Ministério da Agricultura, Pecuária e Abastecimento. Regras para análise de sementes. Brasília: MAPA/ACS,

Brasil (2013). Ministério da Agricultura, Pecuária e Abastecimento. Instrução Normativa n. ${ }^{\circ} 45$ de 17 de setembro de 2013. Padrões para produção e comercialização de sementes de amendoim. Diário oficial da União, n. 181, Seção 1, p. 6.

Christensen, C. M. and Kaufmann, H. H. (1965). Deterioration of stored grains by fungi. Annual Review of Phytopathology, 3, 69-84. http://dx.doi.org/10.1146/annurev.py.03.090165.000441.

Companhia Nacional de Abastecimento (2014). Proposta de preços mínimos. Safra 2013/2014 (Produtos da safra de verão); [acessado em 5 Dez. 2014]. http://www.conab.gov.br/OlalaCMS/uploads/ arquivos/13_11_22_15_41_10_pm_verao_13_14.pdf
Coplana - Cooperativa Agroindustrial (2010). Avaliação da eficiência de diferentes produtos para o controle do percevejo-preto Cyrtomenus mirabilis no amendoim. Revista Técnica Coplana, 2, 32-37.

Delouche, J. C. and Baskin, C. C. (1973). Accelerated aging techniques for predicting the relative storability of seed lots. Seed Science and Technology, 1, 427-452.

Ferreira, D. F. (2014). Software Sisvar: versão 4.6 (build 6.0). Lavras: DEX/UFLA; [acessado em 6 Abr. 2014]. http://www.dex.ufla. $\mathrm{br} / \sim$ danielff/programas/sisvar.html

Hocking, A. D. and Banks, J. H. (1991). Effects of phosphine fumigation on survival and growth of storage fungi in wheat. Journal of Stored Products Research, 27, 115-120. http://dx.doi. org/10.1016/0022-474X(91)90021-4.

Ito, M. F., Bacchi, L. M. A., Maringoni, A. C. and Menten, J. O. M. (1992). Comparação de métodos para detecção de Aspergillus spp. e Penicillium spp. em sementes de amendoim (Arachis hypogaea L.). Summa phytopathologica, 18, 262-268.

Machado, J. C. (1988). Tratamento de sementes: fundamentos e aplicações. Brasília: MEC/ESAL/FAEPE.

Marchi, J. L., Cícero, S. M. and Gomes Junior, F. G. (2011). Utilização da análise computadorizada de plântulas na avaliação do potencial fisiológico de sementes de amendoim tratadas com fungicida e inseticida. Revista Brasileira de Sementes, 33, 652-662. http://dx.doi.org/10.1590/S0101-31222011000400007.

Marcos Filho, J. (1999). Teste de envelhecimento acelerado. In F. C. Krzyzanowski, R. D. Vieira and J. B. França Neto (Eds.), Vigor de sementes: conceitos e testes (p. 1-24). Londrina: ABRATES.

Marcos Filho, J. (2005). Fisiologia de sementes de plantas cultivadas. Piracicaba: FEALQ.

Menten, J. O. M. (1991). Patógenos em sementes: detecção, danos e controle químico. Piracicaba: ESALQ/FEALQ.

Moraes, S. A. and Mariotto, P. R. (1985). Diagnóstico da patologia de sementes de amendoim no Brasil. Revista Brasileira de Sementes, 7, 41-44. http://dx.doi.org/10.17801/0101-3122/rbs.v7n1p41-43. 
Nakagawa, J. and Rosolem, C. A. (2011). O amendoim: tecnologia de produção. Botucatu: FEPAF.

Nóbrega, F. V. A. and Suassuna, N. D. (2004). Análise sanitária de sementes de amendoim (Arachis hypogaea L.) armazenadas em algumas áreas do Estado da Paraíba. Revista de Biologia e Ciências da Terra, 4, 1-9.

Santos, F., Medina, P. F., Lourenção, A. L., Parisi, J. J. D. and Godoy, I. J. (2013). Qualidade de sementes de amendoim armazenadas no estado de São Paulo. Bragantia, 72, 310-317. http://dx.doi. org/10.1590/brag.2013.029.
Schuab, S. R. P., Braccini, A. L., França Neto, J. B., Scapim, C. A. and Meschede, D. K. (2006). Potencial fisiológico de sementes de soja e sua relação com a emergência das plântulas em campo. Acta Scientiarum Agronomy, 28, 553-561.

Smith, J. E. and Ross, K. (1991). The toxigenic Aspergilli. InJ. E. Smith and R. S. Anderson, Mycotoxins and animal foods (p. 101118). Boca Raton: CRC Press.

Thiessen, L. D. and Woodward, J.E. (2012). Diseases of peanut caused by soilborne pathogens in the southwesternUnited States. ISRNAgronomy, 2012, Article ID 517905. http://dx.doi.org/10.5402/2012/517905. 